\title{
Pedological Features of Red Clays in Northern Hungary
}

\author{
J. FEKETE and P. STEFANOVITS
}

Szent István University, Faculty of Agricultural and Environmental Sciences, Gödöllö (Hungary)

Different views on the formation, properties and distribution of red soils in Hungary have been published by several authors. Geologists took an early stand on the origin of red clays. The formation of the several red coloured clays and silts were variously explained, with opinions sometimes contradicting one another. STEFANOVITS $(1959,1963,1967)$ discovered that the red clays of Hungary are genetically diverse.

Hungarian red clays differ greatly in their genetics and their physical and chemical characteristics from other domestic soil types and also from red clays found elsewhere (FEKETE, 1989, 1995, 1998; FEKETE et al., 1997). We would like to add to and clarify the understanding of red clays by undertaking a more detailed study into their distinguishing characteristics and common features, which may assist in evaluating their economic value also. Our red clays are similar to the tropical and sub-tropical ferrallic soils in relation to their formation and mineral characteristics. One of our aims is to explore the similarities in processes and characteristics, which would substantially help in classification. In this paper the results of soil studies carried out on red clays and soils in Northern Hungary are presented.

\section{Materials and Methods}

In order to study red clays we collected samples from nearly one hundred soil profiles from different parts of the Northern Mountainous Region. From the numerous samples results from 16 soil profiles are presented in our study. This selection of samples was chosen with the aim of representing the different types and sources of red clays.

Chemical analysis of the soil's mineral fraction was carried out according to SzÜCS (In: BALLENEGGER, 1962) and well as by the modified MAUL method (1965). In order to identify mineral composition we used X-ray diffraction and

Correspondence to: Dr. József FEKETE, Szent István University, Faculty of Agricultural and Environmental Sciences, Department of Soil Science and Agricultural Chemistry. H-2103 Gödöllö, Páter K. u. 1. Hungary. 
derivatographic thermal methods. The X-ray diffraction and thermo-analytical studies were carried out at the Geological Engineering Department of the Technical University of Budapest (BIDLÓ, 1974).

\section{Analytical Results and Assessment}

The results of the total chemical analyses are recorded in Table 1. The mineral composition of the original soil and sieved fractions are shown in Table 2.

Total chemical analytical data was considered important both in order to identify the age of the soils and also to judge the weathering characteristics. From the total chemical analyses the $\mathrm{SiO}_{2}, \mathrm{Al}_{2} \mathrm{O}_{3}$, and $\mathrm{Fe}_{2} \mathrm{O}_{3}$ values and ratios in percentage terms for both the entire soil and for the clay fraction are presented (Table 1). Depending on the quality and structure of the clay minerals, the data indicates that in the original samples the percentage of $\mathrm{SiO}_{2}$ is higher, while in the clay fraction the values of $\mathrm{Al}_{2} \mathrm{O}_{3}$, and $\mathrm{Fe}_{2} \mathrm{O}_{3}$ are higher. For strongly weathered clay soils (i.e. Aggtelek and Jósvafö soils) there is actually no difference between the chemical composition of the total soil and the clay fraction.

The $\mathrm{SiO}_{2} / \mathrm{R}_{2} \mathrm{O}_{3}$ molecular ratio refers to the nature of weathering. For the Aggtelek and Cserépfalu complete soil samples the observed smaller ratio suggests an intense ferrallitic weathering. On this basis we can state definitely, for these two soils only, that they have remained in their place of formation and have not mixed with other material, and that they are tropical or sub-tropical weathering products.

The $\mathrm{SiO}_{2} / \mathrm{R}_{2} \mathrm{O}_{3}$ molecular ratios of the clay fraction are much lower, but do not all suggest a definite ferrallitous weathering. The ratios often show a value around 2.0 for samples (e.g. Mád, Aggtelek, Jósvafö, Bódvaszilas) and for the samples of deeply buried soil strata such as Nagygombos, Kartal and Gödöllö. It is likely that those soils (or red clays) with higher ratios have resulted from previous inversion processes and surface rearrangements, and are thus mixed compositions of assorted weathered products. We can assume that the lower these ratios are the stronger the earlier tropical or sub-tropical weathering processes were. Usually kaolinite occurs or is even dominant among the clay minerals in the case of soils with a lower $\mathrm{SiO}_{2} / \mathrm{R}_{2} \mathrm{O}_{3}$ ratio, which also suggests intense weathering and transforming processes.

On examination of the mineral composition (Table 2) identified by thermal analysis and X-ray diffraction, the following observations were made. Information on mineral composition is of decisive importance in identifying the age and weathering processes of red clays and also in assessing numerous characteristics of these clays. 


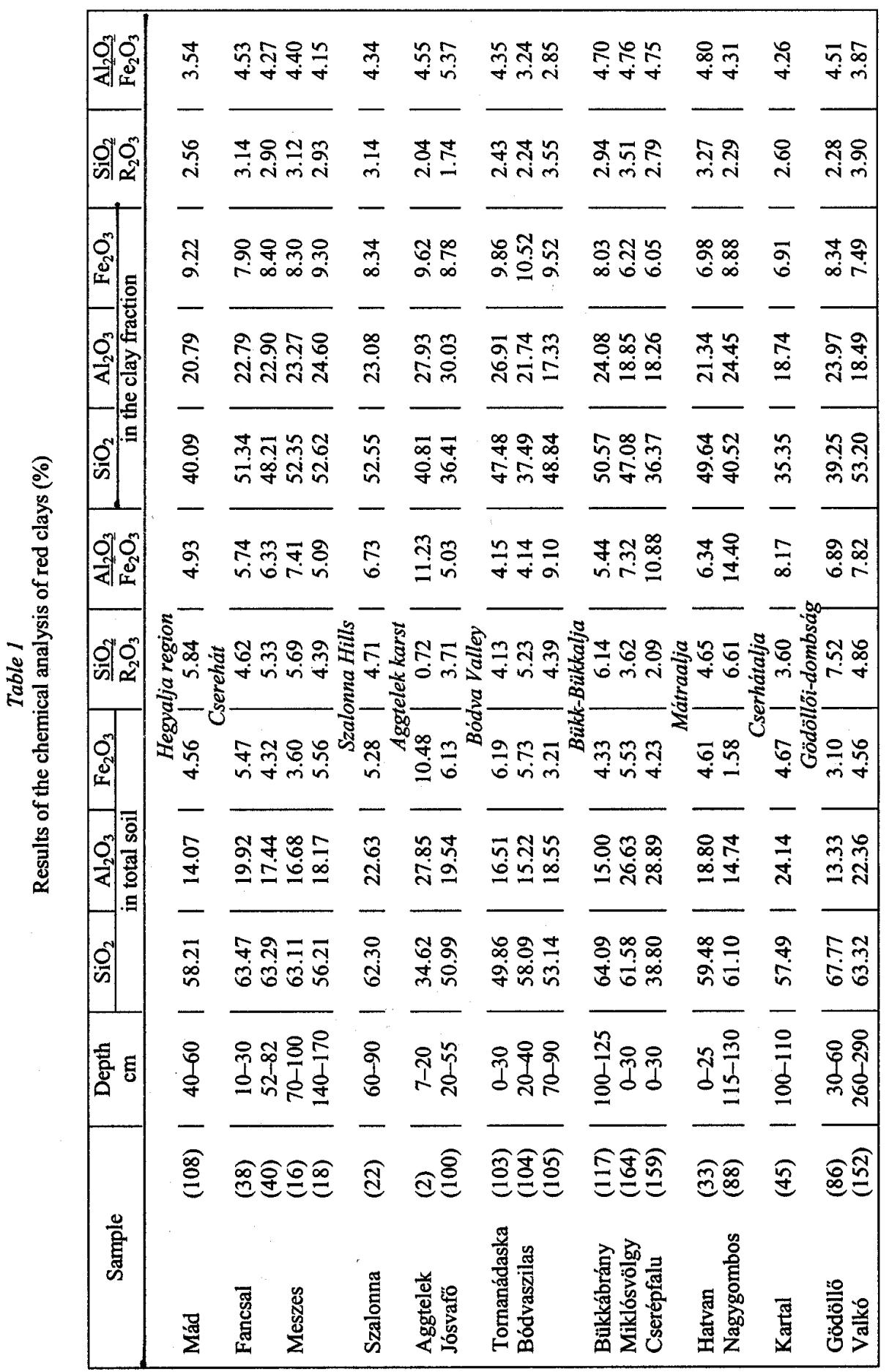




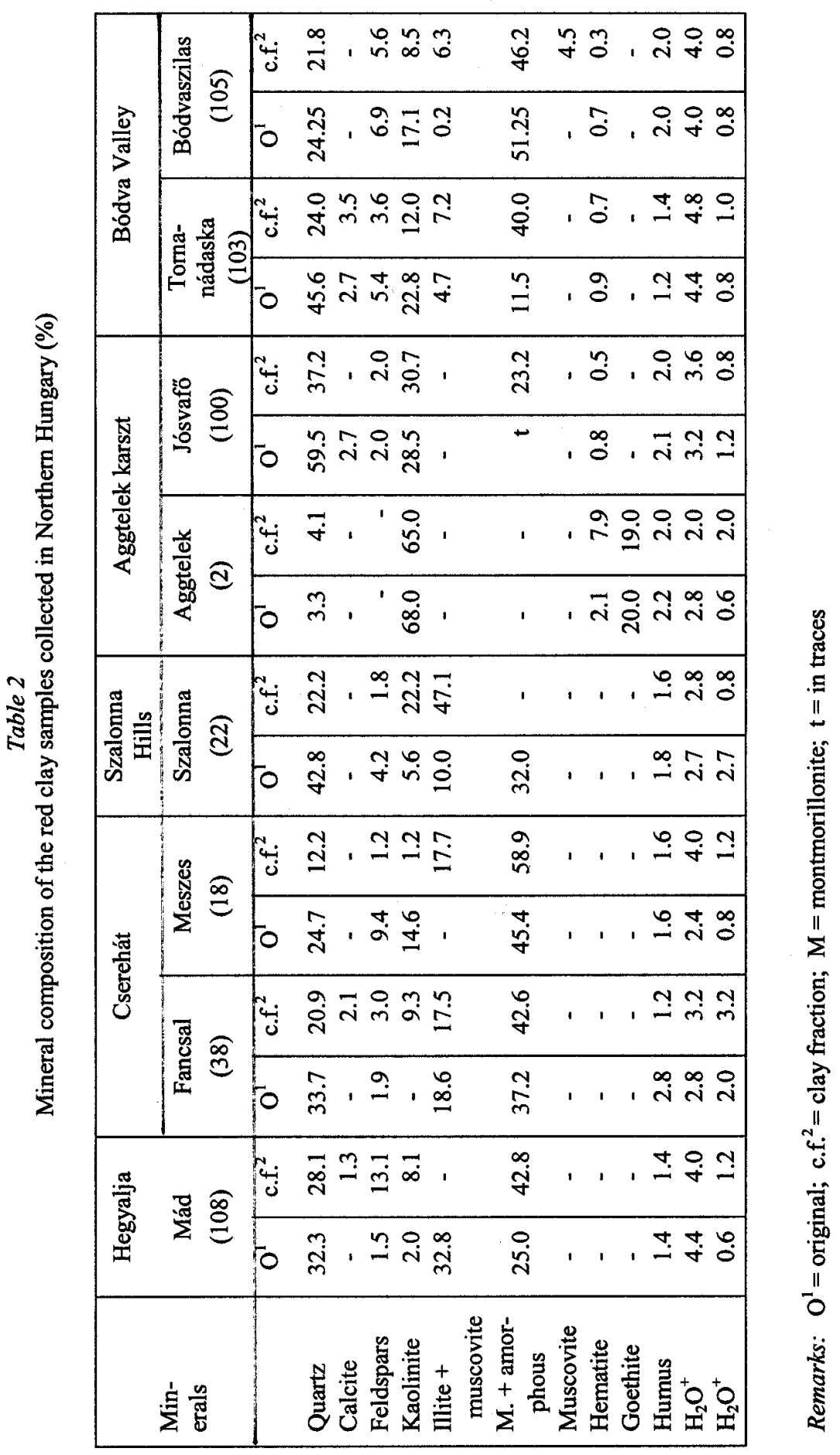




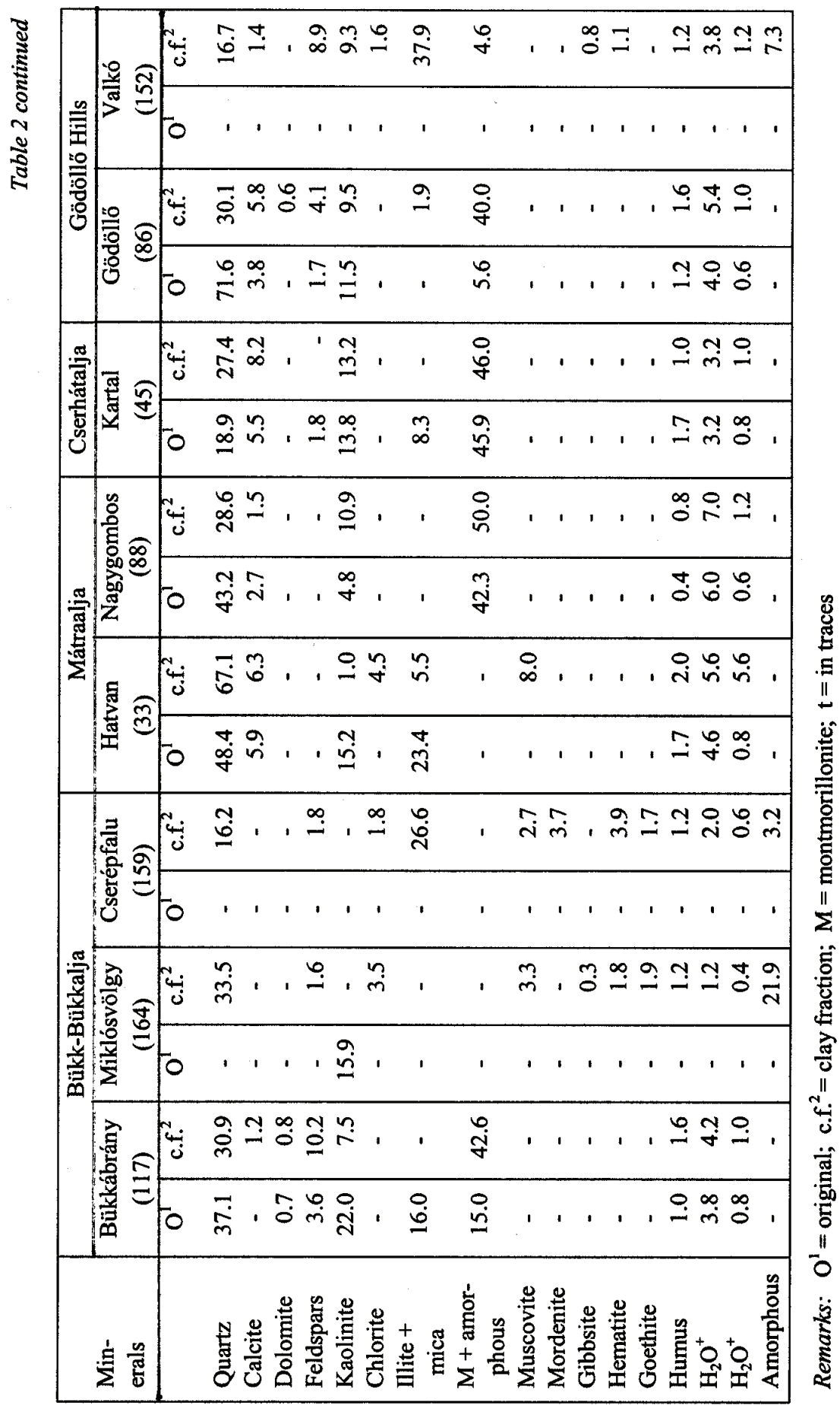


1. Red clay of the Hegyalja region (Tokaj foothills), which is represented by the Mád sample. Its quartz content is $30 \%$, illite content 33\%, montmorillonite around $43 \%$ and kaolinite occurs only in a few percents. It neither contains geothite nor hematite. The red clay (,nyirok"), formed on rhyolite tuff is found on several sites in the Tokaj-Hegyalja region.

2. The red soils of the Cserhát and Szalonna Hills have a significant quartz content, illite and mica can be found in 10-17\% and feldspar in a few percents. The montmorillonite content is relatively high (varying between 32-59\%). Hematite and geothite are undetectable, their red coloration derives from the amorphous ironoxyde hydrates.

3. The red clays of the Aggtelek-karst, the Torna Hills and the Bódva Valley, with a clay content of $60-80 \%$. While sharing similarities in their mineral composition, certain differences are noted. In the Aggtelek sample the amount of quartz is very low, while the amount of kaolinite is extremely high. In the other samples the quartz content is medium or high, the kaolinite is lower (varying between $8-28 \%$ ), the amount of montmorillonite is around $40 \%$. They do not contain hematite or geothite.

4. The red soils of the Bükk mountain range are moderately heavy clays with a quartz content between $16-33 \%$. In these clays kaolinite is present in small quantities, illite exceeds $20 \%$, but they do not contain montmorillonite. There were a few percents of hematite and geothite in the samples, and one sample contained gibbsite. These red clays are found on limestone.

5. The red clays of the northern periphery of the Great Hungarian Plain are characterized by a $30-60 \%$ quartz content. These soils contain small quantities of calcite and feldspar, while kaolinite is generally present at concentrations of $10-20 \%$, with a low percentage of illite. There is a substantial montmorillonite content (40-50\%). Under the red soils on the border of the Great Plain, clay, silt or even sand layers of various origins are to be found. These clays are soils formed during the transition from the Pliocene to the Pleistocene, or are paleosoils formed during the Pleistocene.

\section{Different moisture forms and differentiated pore space of red clays}

Figures 1 and 2 show the data of different forms of moisture, total pore space and differentiated porosity.

Values of unavailable water were calculated from hygroscopic moisture content values according to KLIMES-SzMIK (1962). The calculated amount of unavailable water increased in the order: Aggtelek (Béke barlang), Jósvafö. This was related to the clay content. The amount of clay in the profile near Békebarlang was 58-67\%, and that of the Jósvafö profile around 75-79\%.

The different water capacity values were the highest in the profile Jósvafö. 

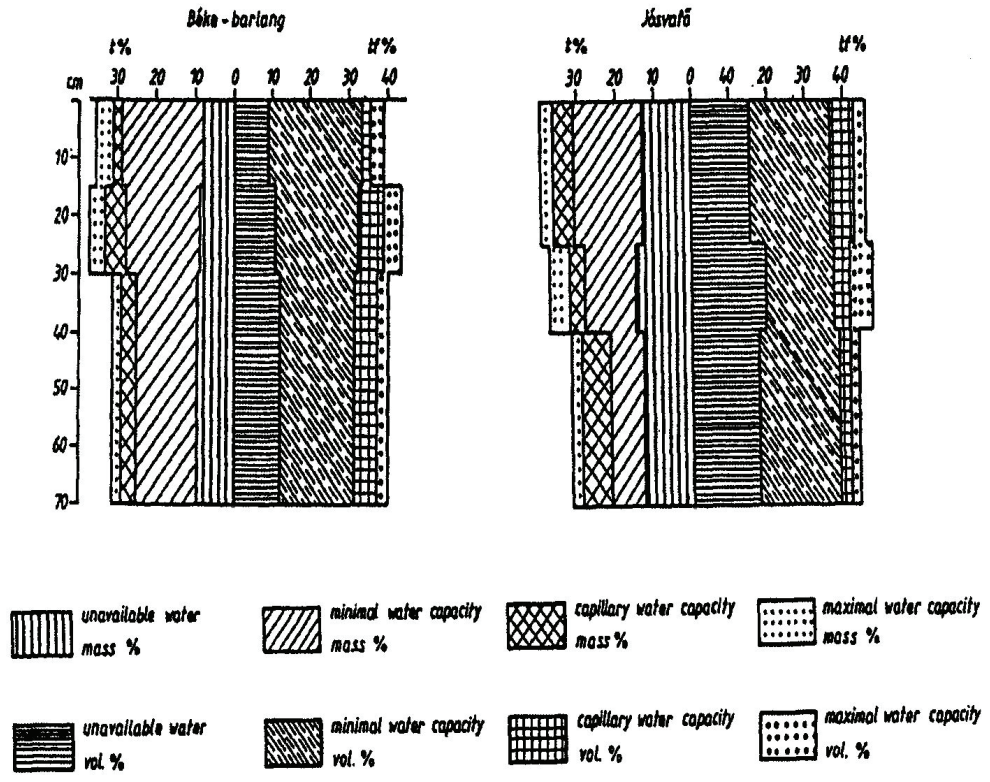

Figure 1

Values of unavailable water and water capacity (Aggtelek, Jósvafó)
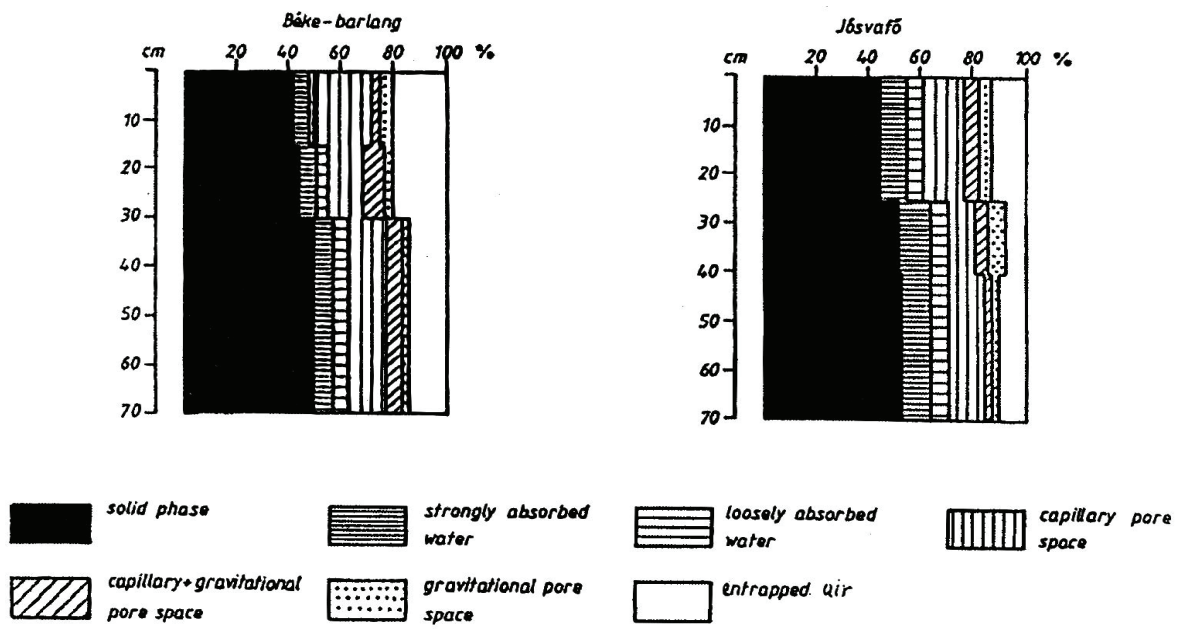

Figure 2

Differentiated porosity, expressed in \% of total porosity

(Aggtelek, Jósvafö) 
The distribution of pores of different quality and size was characterized by a high percentage of medium size pores (capillary pores and the pore space of entrapped air). The pore space of the entrapped air was considered as being of medium size, assuming that air remained in them in the case of capillary saturation. The space of fine pores (pore space of strongly and loosely absorbed water) and the space of coarse pores (total gravitational pore space and gravitational capillary pore space) were relatively small.

In soils with higher montmorillonite contents the water capacity values were also higher. The distribution of fine, medium size and coarse (macro) pores was more uniform than in any other group of soils.

Red clays containing the clay mineral kaolinite and characterized by bauxitic mineral composition contained less absorbed water.

Red clays that contained higher amounts of montmorillonite expanded considerably when they were saturated with water and contracted when they were dried. The difference between the volume density and pore space of wet and dry soil was substantial. The difference in pore space was about $7-10 \%$.

\section{Water permeability}

The water permeability of the original structure of some of the samples was determined. The investigations were carried out in a laboratory according to KLIMES-SZMIK (1962) (Figure 3)
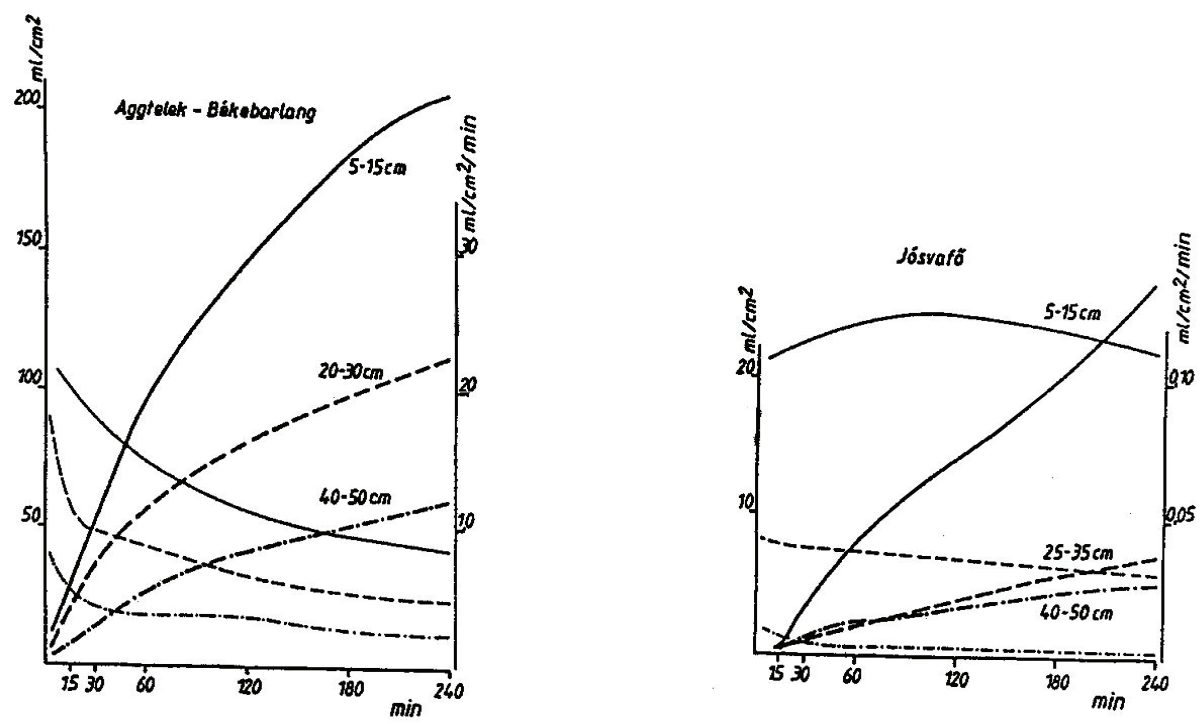

Figure 3

Water permeability curves Aggtelek (Békebarlang), Jósvafö 
The water permeability of the soil profiles was proportional to the pore space conditions. The total pore space was highest in the Aggtelek samples, lower in the Jósvafó samples. Water permeability was also correlated with the ratio of coarse (macro) pores. The higher water permeability of the soils near Békebarlang was related to better structure and dense root system. Water permeability correlated best with the total number of medium and coarse pore spaces.

\section{Summary}

On the basis of the samples studied, which were gathered over the past year, we were able to summarize the characteristics of red clays in Northern Hungary. From the large selection of samples we chose 16 representative soil profiles for our assessment. In order to characterize red clays we used data on mechanical composition, cation exchange capacity and adsorption capacity as well as the mineral composition identified by X-ray diffraction and thermoanalytical studies. Following observations and conclusions drawn from our study we were able to identify the categories of red clay in Northern Hungary:

1. Red clay of the Hegyalja region (Tokaj foothills);

2. Red soils of the Cserhát and Szalonna Hills;

3. Red clays of the Aggtelek karst, the Torna Hills and the Bódva Valley;

4. Red soils of the Bükk mountain range.

5. Red clays of the Northern periphery of the Great Hungarian Plain.

The following conclusions can be drawn from the studies on the water permeability of the soils:

Water permeability is correlated with the pore space and the ratio of coarse pores. The bigger the total pore space and the ratio of coarse pores, the better the water permeability of the soil.

If the clay content is higher the water permeability is generally lower. In soils that contain montmorillonite the speed of water permeability is lower than in soils containing kaolinite. Within the porous system of bauxitic red clays con-taining kaolinite the volume of medium size and coarse pores increases, result-ing in better water permeability.

In the upper layers of soils covered with vegetation water permeability is much better. The high amount of roots and root residues provides better soil structure and porosity, thus improving water permeability.

Key words: red clay, ferrallic soil, mineral composition, differentiated pore space

This research was supported by the National Scientific Research Fund (OTKA) under Grant No. T 032579. 


\section{References}

BAlLENEGGeR, R. \& Di GlériA, J., 1962. Methods for Soil and Agrochemical Analysis. (In Hungarian). Mezőgazdasági Kiadó. Budapest.

FEKETE, J., 1989. Examination of some physical properties of tropical soils. Bulletin of the University of Agricultural Sciences, Gödöllö. 51-58.

FeKETE, J., 1995. Comparative study of some physical and chemical properties of tropical soils. Bulletin of the University of Agricultural Sciences, Gödöllö. $75^{\text {th }}$ Anniversary Edition. I. 65-76.

FeKETE, J., 1998. Water regime and porous system of red clays in Hungary. Acta Agron. Hung. 46. 341-353.

Fekete, J., Stefanovits, P., BidLó, G., 1997. Comparative study of the mineral composition of red clays in Hungary. Acta Agron. Hung. 45. 427-441.

KLIMES-SzMIK, A., 1962. Classification of the pore spaces of the soil on the basis of water movement. (In Hungarian) Agrokémia és Talajtan. 11. 41-54.

MAUL, F., 1965. Rapid method for the analysis of mineral fractions of soils. (In Hungarian) Agrokémia és Talajtan. 14. 238-248.

PÉCSI, M., 1985. The Neogene red clays of the Carpathian Basin. Studies in Geography in Hungary. 19. 89-98. Akadémiai Kiadó. Budapest.

Stefanovits, P., 1959. Spatial distribution and properties of red clays in Hungary. (In Hungarian) Bulletin of the Agronomy Department, Hungarian Academy of Sciences. 16. 225-238.

Stefanovits, P., 1963. Soils of Hungary. (In Hungarian) Akadémiai Kiadó. Budapest.

Stefanovits, P., 1967. Signs of Mediterranean soil formation in Hungary. (In Hungarian) Bulletin of the University of Agricultural Sciences, Gödöllő. 227-235. 